Dept of Animal Disease,

Faculty of Veterinary Medicine, Hama, Al-Baath University, Syria.

\title{
ISOLATION AND MOLECULAR DETECTION OF INFECTIOUS LARYNGOTRACHEITIS VIRUS IN LAYERS AND BROILER BREEDERS IN SYRIA
}

(With One Table and 3 Figures)

By

M.Y. ARNAOUT; M.M. FADEL and I.M. MOHRA*

* Dept. Animal Production, Fac. of Agriculture, Damascus University, Syria.

(Received at 7/9/2009)

العزل والكثف الجزيئي عن فيروس مرض التهاب الحنجرة والرغامى المعدي

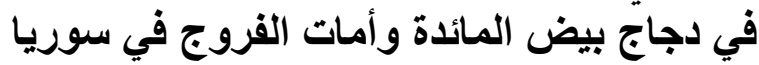

ماهر باسبين الارناؤوط ، محد مصطفى فاضل ، إبراهيم محد مهرة

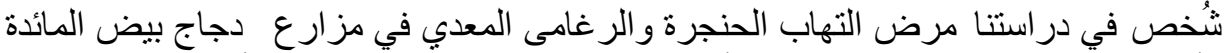

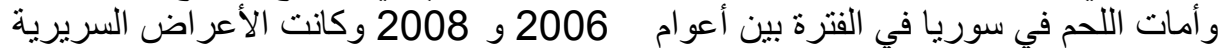

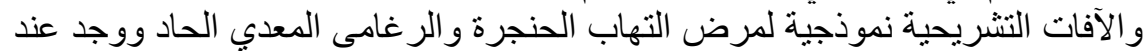

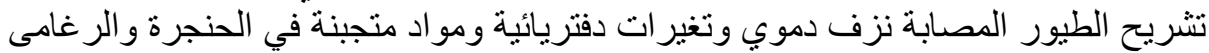

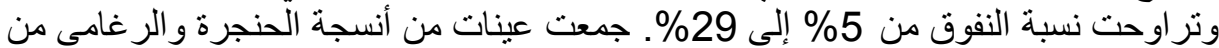

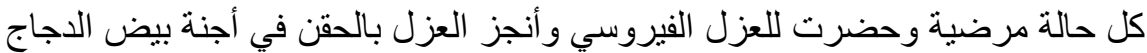

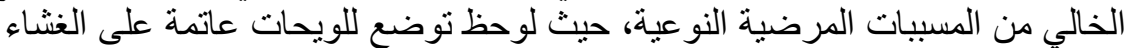

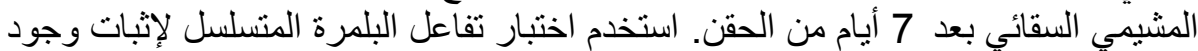

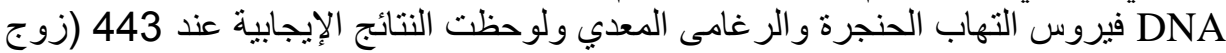

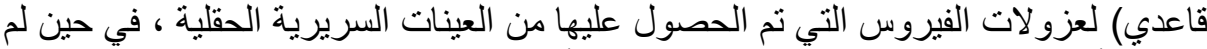

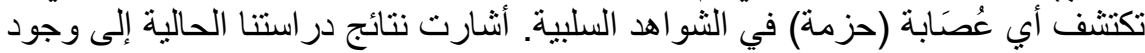

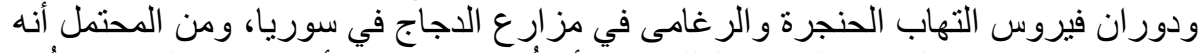

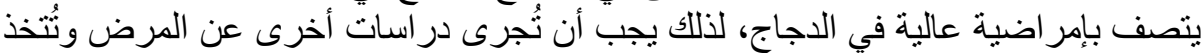
إجر اءات الوقاية للحد من خطورة المرض في سوريا.

\section{SUMMARY}

In this study, Avian Infectious Laryngotracheitis (ILT) was diagnosed in layer and broiler breeder farms in Syria between 2006 and 2008. Clinical signs and gross lesions were typical to acute ILT infections. At necropsy of affected birds, haemorrhage, diphtheritic changes and caseous material were found in trachea and larynx. Mortality rates varied from 
$5 \%$ to $29 \%$. Laryngotracheal tissue samples from each field case were collected and prepared for virus isolation. Virus isolation was carried out by inoculation of embryonated specific pathogen free eggs (SPF). Several opaque plaques on chorioallantoic membrane (CAM) were observed after seven days of inoculation. The polymerase chain reaction PCR was utilized to confirm the presence of ILTV DNA. Positive results by PCR were observed in ILTV isolates obtained from field specimens. No bands were detected in negative controls. Our results indicate the presence and circulation of ILTV in chicken Syrian farms, which probably have a high pathogenicity in the field. Further studies and prevention strategies on avian infectious Laryngotracheitis in Syria should be carried out.

Key words: Infectious Laryngotracheitis virus, Polymerase chain reaction, Virus isolation.

\section{INTRODUCTION}

Infectious Laryngotracheitis (ILT) has been identified in many countries of the world, and still remains a threat to the intensive poultry industry. Recently, ILT infections have occurred in USA and Brazil (Crespo et al., 2007; Chacon et al., 2008). The disease is characterized by depression, conjunctivitis, sneezing, coughing, anorexia, nasal exudates, gasping, and decreases in eggs production. In severe forms of the disease, expectoration of blood-stained mucus and high mortality rate are described (Guy and Bagust, 2003). Mild enzootic forms generally result in low mortality $(0.1 \%-2 \%)$.

Causative agent belongs to the family Herpesviridae viruses, subfamily of Alphaherpesvirinae, Iltovirus genus, and called Infectious Laryngotracheitis virus (ILT) (Davison et al., 2005).

The DNA genome possesses a type D herpesvirus genome (Roizman and Pellet, 2001), consists of a linear 155-kb double-stranded molecule comprised of unique long and short regions flanked by inverted repeats (Lieb et al., 1987; Johnson et al., 1991). Differences between ILTV strains based on virulence studies and restriction fragment length polymorphism analysis were described (Graham et al., 2000; Han and Kim, 2001; Creelan et al., 2006; Ojkic et al., 2006).

ILT Virus was isolated successfully on embryonated chicken eggs (Hughes and Jones, 1988) and in cell culture such as chicken embryo liver (McNulty et al., 1985), chicken embryo kidney (Chang et al., 1960) and chicken kidney (Van Kammen and Spadbrow, 1976). Viral antigens and antibodies may be demonstrated by immunohistochemistry (IHC) 
(Timurkaan et al., 2003), immunofluorescence (IF) (Braune and Gentry, 1985), agar gel precipitation test (AGPT), virus neutralization test (VN) and enzyme linked immunosorbent assay (ELISA) (Bauer et al., 1999).

Several molecular methods including PCR for identifying ILTV DNA in clinical samples have been reported (Keam et al., 1991 and Key et al., 1994). The polymerase chain reaction (PCR) has been used to detect nucleic acid of ILTV in the trachea and other tissues and it is very sensitive in ILT diagnosis (Williams et al., 1992; Abbas et al., 1996; Alexander and Nagy, 1997, and Alexander et al., 1998; Humberd et al., 2002). PCR allows detecting DNA in samples contaminated with other microorganisms, such as adenoviruses, that may prevent ILTV isolation due to overgrowth in culture (William et al., 1994). In current time, the use of PCR for the detection of ILT DNA in clinical cases has become widespread.

In Syria, ILT infections were reported in layers and broiler breeders based on serological tests (Arnaout, 2005). Knowing that, ILT virus wasn't isolated in layers in Syria.

This article describes the diagnosis of acute infectious Laryngotracheitis in layer and broiler breeder farms, and the detection of ILTV isolates by PCR. This work reports the first isolation of ILTV in commercial layer hens in Syria.

\section{MATERIALS and METHODS}

\section{History of examined flocks and samples collection:}

Tissue samples of affected larynx and trachea were obtained from four different commercial layer and broiler breeder chicken flocks from three different regions in Syria between March 2006 and January 2008. No ILT vaccine had been used in these farms. Samples from each case were identified by case code, followed by letters representing country (Syria) and the year of sample collection as described by (Oldoni et al., 2008) (Table 1).

Table 1: The summary of case history to the four ILT suspected flocks.

\begin{tabular}{|l|l|l|l|l|l|}
\hline Case ID/(isolate) & $\mathrm{Y} / O^{1}$ & chicken & $\mathrm{A}^{2} \mathrm{D}^{2}$ & mortality & $\mathrm{N} / \mathrm{B}^{3}$ \\
\hline A2/SY006 & Mar 2006 & layers & 355 & $5 \%$ & 5500 \\
\hline A1/SY006 & Apr 2006 & layers & 28 & $29 \%$ & 14000 \\
\hline B1/SY007 & May 2007 & layers & 133 & $16 \%$ & 5950 \\
\hline D3311/SY008 & Jan 2008 & Broiler breeder & 21 & $25 \%$ & 20400 \\
\hline
\end{tabular}

1 year of occurrence, 2 age in days, 3 number of birds 


\section{Virus isolation:}

Virus isolation of ILTV was carried out according to (Tripathy, 1998; OIE, 2008). Briefly, a pool of 3-4 larynx and trachea tissues from each case were homogenised with PBS $(\mathrm{pH}=7.2)$ and prepared as suspension $20 \%(\mathrm{~W} / \mathrm{V}$ ). The suspension was centrifuged at $5000 \mathrm{rpm}$ for $10 \mathrm{~min}$ in $4{ }^{\circ} \mathrm{C}$ and after filtration the supernatant was inoculated in allantoic cavity or in CAM membrane of 10 days SPF eggs (5 eggs for each) and incubated for 7 days at $37{ }^{\circ} \mathrm{C}$. At least two passages were done. The CAMs after the first and the second passages were examined for the presence of lesions.

MA/SY004 field isolate of ILTV which isolated in previous study from the upper respiratory disease of broiler breeder chickens in Syria in 2004 (Arnaout, 2005) used as positive control, and commercially avian pox virus vaccine from (Lohmann, Germany) used as a negative control.

\section{Extraction of viral DNA:}

DNA was extracted using commercial DNA extraction kit (QiaAmp DNA Mini Kit, Qiagen, Germany) according to the manufacture with the recommendations for viral DNA. Briefly, $20 \mu \mathrm{l}$ of proteinase $\mathrm{K}$ was added to $200 \mu \mathrm{l}$ aliquots of supernatants from homogenized CAMs, then $200 \mu \mathrm{l}$ of lysis buffer AL was added, and the mixture incubated at $56{ }^{\circ} \mathrm{C}$ for $10 \mathrm{~min}$. The protein free DNA was precipitated with $260 \mu \mathrm{l}$ of ethanol. The solution was transferred to QIAamp Mini spin column and centrifuged at $8000 \mathrm{rpm}$ for $1 \mathrm{~min}$. Two washings steps were performed: The first with $500 \mu \mathrm{l}$ AW1 (centrifuged for $1 \mathrm{~min}$ at $8000 \mathrm{rpm}$ ), the second with $500 \mu \mathrm{l} \mathrm{AW} 2$ (centrifuged for 1 min at $14000 \mathrm{rpm})$. DNA was eluted with $100 \mu \mathrm{l}$ AE buffer from QiaAmp column (centrifuge at $14000 \mathrm{rpm}$ for $1 \mathrm{~min}$ ). The DNA was stored at $70-{ }^{\circ} \mathrm{C}$.

\section{Polymerase Chain Reaction:}

Amplification of extracted DNA was performed by one-step PCR with a commercial complete kit (Avian Infectious Laryngotracheitis kit, serial number 2918, GeneKam Biotechnology AG, Germany). The kit contains [solution A, solution B] which included PCR master mix and ILTV specific primers (forward and backward) (Alexander et al., 1998). The procedure was carried out according to manufacturer. Briefly, a 20 $\mu \mathrm{l}$ final PCR reaction mixture contained $2 \mu \mathrm{l}$ of DNA template added to $10 \mu \mathrm{l}$ of solution B and $8 \mu \mathrm{l}$ of solution A. The reaction mixture was incubated in theromcycler (TECHNE TC-512, England), at initial denaturation $94^{\circ} \mathrm{C}$ for $1 \mathrm{~min}$, followed by 35 cycles at $95^{\circ} \mathrm{C}$ for 20 
seconds, $60^{\circ} \mathrm{C}$ for 90 seconds, $72^{\circ} \mathrm{C}$ for 90 seconds, and a final extension at $72{ }^{\circ} \mathrm{C}$ for 300 seconds. PCR product was fractionated by electrophoresis using a 1.5\% agarose gel in $1 \mathrm{X}$ TAE buffer (Agarose, 25x TAE, Biobasic, Canada) containing ethidium bromide $(5 \mu \mathrm{l} / 100 \mathrm{ml})$. Sample that generated the expected product band at 443 bp was considered positive for ILTV according to manufacturer instructions.

\section{RESULTS}

\section{Clinical signs and post mortem lesions:}

The affected birds had shown severe respiratory signs including gasping, coughing, gurgling, open mouth and extended neck, asphyxia, and blood-stained mucus which observed on the wall of poultry houses, accompanied by increased mortality and high morbidity.

At necropsy of affected birds, the gross lesions were located mainly in the upper respiratory tract, while other tissues were normal in euthanized birds. These lesions consisted of mild-sever congestion with haemorrhage in trachea, mucus mixed with blood along trachea, a plug of caseous material in the entryway of larynx and diphtheritic membranes adherent to the larynx and trachea.

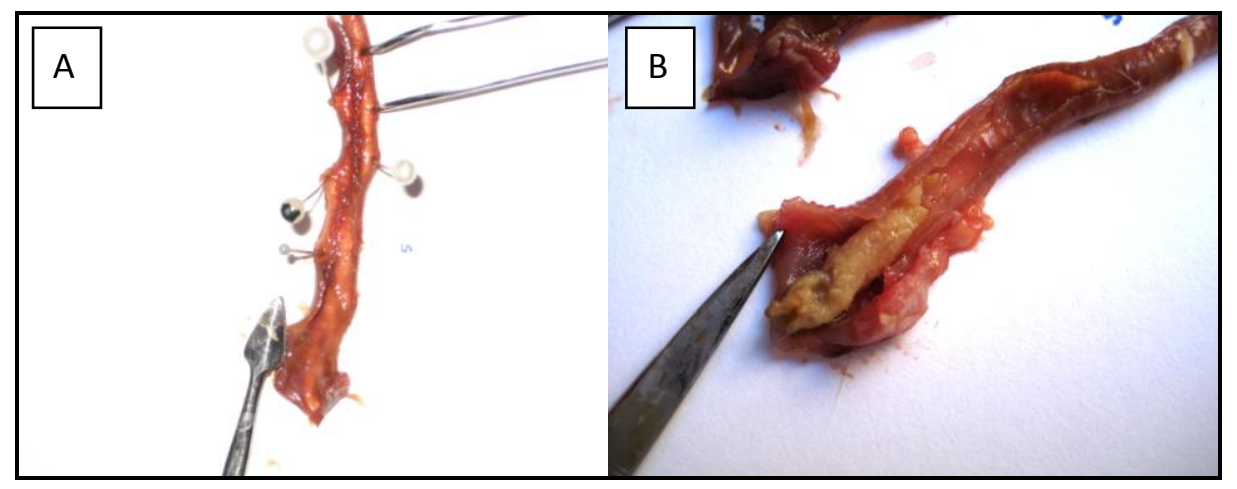

Fig. 1: Gross lesions observed in (D3311/SY008) ILT field case A; haemorrhage and congestion in trachea, B; a plug of caseous material in the larynx.

\section{Virus Isolation:}

ILTV was isolated from each case when inoculated via chorioallantoic membrane (CAM). In the first and the second passage, dispersed opaque plaques (pocks) and edema on the CAMs were observed seven days post-inoculation (Figure 2). 


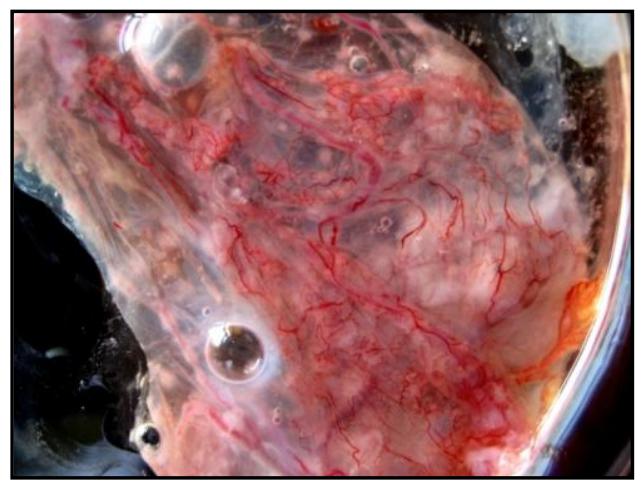

Fig. 2: Opaque plaques on CAM of chicken embryos inoculated with ILTV.

\section{Polymerase Chain Reaction:}

As shown in Figure 3, the expected fragment of $443 \mathrm{bp}$ of ILTV DNA was detected in A1/SY006, A2/SY006, B1/SY007 and D3310/SY008 ILTV isolates, as well as in the two positive controls. No bands were detected in negative contiol, dH2O, rwormal CAM, AF' vaccine, normal

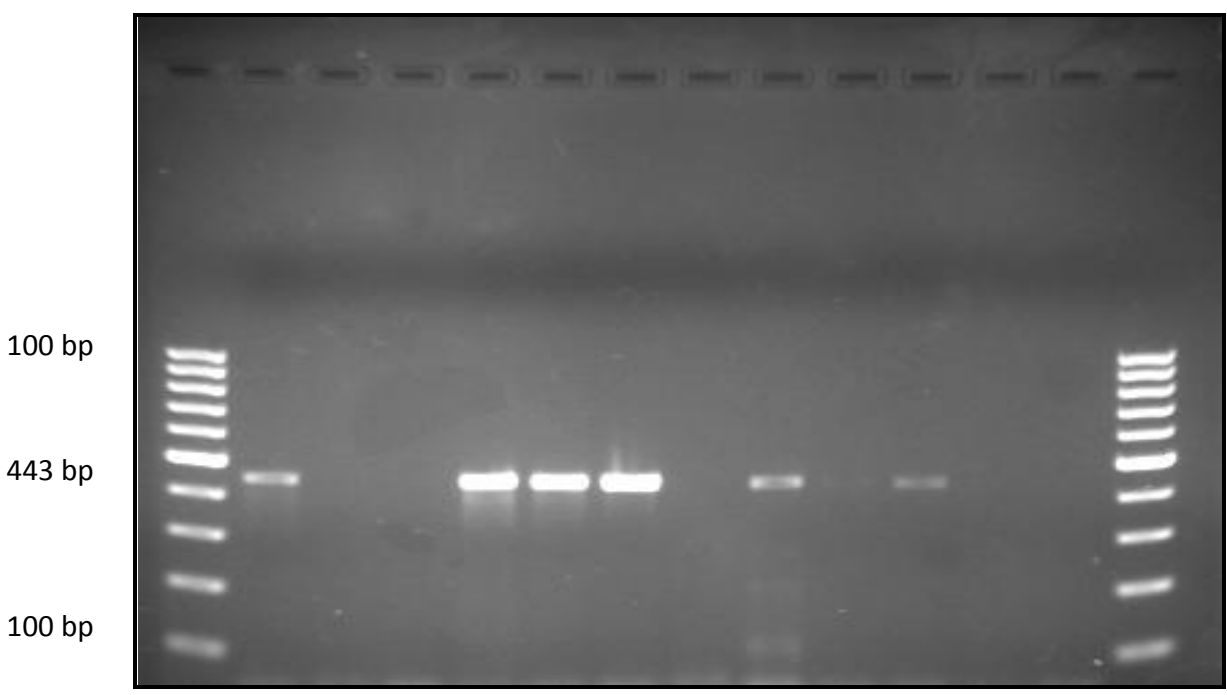

Fig. 3: 01- Molecular Ladder 100bp (Genekam), 02- Positive control (GeneKam), 03- Negative control (GeneKam), 04- dH2O, 05A2/SY006 isolate, 06- MA/SY004, isolate 07- B1/SY007 isolate, 08- normal CAM from SPF egg, 09- D3310/SY008 isolate, 10Avian Pox vaccine, 11- A1/SY006 isolate, 12-trachea from uninfected bird, 13- PBS pH = 7.2, 14- Molecular ladder $100 \mathrm{bp}$. 


\section{DISCUSSION}

Laryngotracheitis still threats poultry industry around the world. In Syria, previous serological screening on ILT in chicken farms indicated to presence of ILTV antibodies in layers and broiler breeders, and one ILT virus isolate was obtained from a broiler breeder flock (Arnaout, 2005).

In the present study, acute infectious Laryngotracheitis was diagnosed in three field cases in layers and one field case in broiler breeders by clinical signs, gross lesions and virus isolation and PCR.

In our study, clinical signs and lesions in the field cases such as dyspnea, expectoration of bloody mucus and haemorrhage in trachea were observed, which associated with high mortality rates varied from $5 \%$ to $29 \%$. These findings are typical to the ILT disease (Guy and Bagust, 2003), Similar findings were described for severe epizootic forms of ILT infections (Jordan, 1958).

ILT virus was isolated in each cases by inoculation in SPF chicken eggs. The virus caused pocks formation on CAM after inoculation, which is characteristic of ILT virus (Tripathy, 1998). The virus isolates obtained from these cases were easily propagated in embryonating chicken eggs, and that refer to the virulence of the strain. Hughes et al. (1991) and Garcia and Riblet (2001) explained the difficult of isolation of low virulent ILTV, also Sellers et al. (2004) described the limited propagation of ILT virus isolated from mild cases.

Polymerase chain reaction applied to viral diagnosis is a highly sensitive technique (Forghani and Erdman, 1994), and shown to be more sensitive in DNA detection than other tests (Abbas et al., 1996). Alexander and Nagy (1998) used PCR to amplify DNA from Ontario and New Brunswick ILTV isolates. In the present study, ILTV isolates were analyzed by PCR to amplification and confirming of nucleic acid. Positive results of ILTV DNA were obtained at 443 bp as expected, while no bands were seen in all negative controls. A benefit of one stepPCR using the PCR kit mentioned herein is reducing pipetting steps, which decreases the risk of contamination.

Our results of virus isolation and PCR are in agreement with the characteristic symptoms and lesions of avian infectious Laryngotracheitis virus observed in the field. These correlations are very significant in diagnosis of ILTV (Chacon et al., 2007). In this work, we conclude the presence of ILT virus in layer and broiler breeder chickens in Syria, and it is may be responsible for significant economical losses in 
chicken farms. The circulating virus strain probably has a high virulence in chickens. Therefore, adequate applications for controlling of ILT should be done. However further pathogenicity, molecular and epidemiological studies are still carrying out on Laryngotracheitis virus isolates in Syria.

\section{ACKNOWLEDGMENTS}

The authors thank Dr. Zohair AL Ahmad, Faculty of Veterinary Medicine, University of AL Baath, Syria, for his kind scientific support about polymerase chain reaction.

\section{REFERENCES}

Abbas, F.; Andreasen, J.R. and Jackwood, M.W. (1996): Development of a polymerase chain reaction and a non radioactive DNA probe for infectious Laryngotracheitis virus. Avian Dis., 40: $56-62$.

Alexander, H.S.; Douglas, W.K. and Nagy, E. (1998): Analysis of Infectious Laryngotracheitis Virus Isolates from Ontario and New Brunswick by the Polymerase Chain Reaction. Can. J. Vet. Res., 62: 68-71.

Alexander, H.S. and Nagy, E. (1997): PCR to detect infectious Laryngotracheitis virus in conjunctival swabs from experimentally infected chickens. Avian Dis., 41: 646-653.

Arnaout, M. (2005): Serological study of infectious Laryngotracheitis in chickens in Syria. (M. SC. Thesis). Veterinary Medicine Faculty, University of AL-baath, Syria, pp 175.

Bauer, B.; Lohr, J.E. and Kaleta, E.F. (1999): Comparison of commercial ELISA test kits from Australia and the USA with the serum neutralization test in cell culture for the detection of antibodies to the infectious Laryngotracheitis virus of chickens. Avian Pathol., 28: 65-72.

Braune, M.O. and Gentry, R.F. (1985): Standardization of the fluorescent antibody technique for the detection of avian respiratory viruses. Avian Dis., 9: 535-545.

Chacon, J.L.; Brandao, P.E.; Villarreal, L.Y.; Gama, N.M. and Ferreira, A.J. (2007): Survey of Infectious Laryngotracheitis Outbreak in Layer Hens and Differential Diagnosis with other Respiratory Pathogens. Brazilian Journal of Poultry Science., 9: 61-67. 
Chacon, J.L.; Antonio, J. and Ferreira, P. (2008): Development and validation of nested-PCR for the diagnosis of clinical and subclinical infectious Laryngotracheitis. Journal of Virological Methods., 151: 188-193.

Chang, P.W.; Yates, V.J.; Dardiri, A.H. and Fry, D.E. (1960): Some observations on the propagation of infectious Laryngotracheitis virus in tissue culture. Avian Dis., 4: 384-390.

Creelan, J.L.; Calvert, V.M.; Graham, D.A. and McCullough, S.J. (2006): Rapid detection and characterization from field cases of infectious Laryngotracheitis virus by real-time polymerase chain reaction and restriction fragment length polymorphism. Avian Pathol., 35: 173-179.

Crespo, R.; Woolcock, P.R.; Chin, R.P.; Shivaprasad, H.L. and Garcia, $M$. (2007): Comparison of diagnostics techniques in an outbreak of infectious Laryngotracheitis from meat chickens. Avian Dis., 51: 858-862.

Davison, A.J.; Eberle, R.; Hayward, G.S.; McGeoch, D.J.; Minson, A.C.; Pellet, P.E.; Roizman, B.; Studdert, M.J. and Thiry, E. (2005): Family Herpesviridae. In Virus Taxonomy: Eighth Report of the International Committee on Taxonomy of Viruses, pp. 193-212. Edited by C.M. Fauquet, M.A. Mayo, J. Maniloff, U. Desselberger and L.A. Ball. San Diego, CA: Academic Press.

Forghani, B. and Erdman, D.D. (1994): Amplification and detection of viral nucleic acids. In: Schmidt JN, Emmons RW. Diagnostic procedures for viral, rickettsial and chlamydial infections. Washington, DC: American Public Health Association,. p. 97-120.

Fulton, R.M.; Schrader, D.L. and Will, M. (2000): The route of vaccination on the prevention of infectious Laryngotracheitis in commercial egg- laying chickens. Avian Dis., 21: 185-194.

Garcia, M. and Riblet. S. (2001): Characterization of infectious Laryngotracheitis virus (ILTV) isolates: demonstration of viral subpopulations within vaccine preparations. Avian Dis., 45: 558-566.

Graham, I.E.; McLaren, V.; Calvert, D.; Torrens and Meehan, B.M. (2000): RFLP analysis of recent Northern Ireland isolates of infectious Laryngotracheitis virus: comparison with vaccine virus and field isolates from England, Scotland and the Republic of Ireland. Avian Pathol., 29: 57- 62. 
Guy, J.S. and Bagust, T.J. (2003): Laryngotracheitis. In. Saif Y.M.; Barnes, H.J.; Glisson, J.R.; Fadley, A.M.; Mc Dougald, L.R. and Swayne, D.E. (Eds.), Diseases of Poultry, $11^{\text {th }}$ edn (pp. 121 -134). Ames: Iowa State Press.

Han, M.G. and Kim, S.J. (2001): Comparison of virulence and restriction endonuclease cleavage patterns of infectious Laryngotracheitis viruses isolated in Korea. Avian Pathol., 30: 337- 344

Humberd, J.; Garcia, M.; Riblet, S.; Resurreccion, R.S. and Brown, T.P. (2002): Detection of infectious Laryngotracheitis virus in formalin-fixed paraffin embedded tissues by nested polymerase chain reaction. Avian Dis., 46: 64-74.

Hughes, C.S. and Jones, R.C. (1988): Comparison of cultural methods for primary isolation of infectious Laryngotracheitis virus from field material. Avian Pathol., 17: 295-303.

Hughes, C.S.; Williams, R.A.; Gaskell, R.M.; Jordan, F.T.W.; Bradbury, M.; Bennett, M. and Jones, R.C. (1991): Latency and reactivation of infectious Laryngotracheitis vaccine virus. Arch. Virol., 121: 213-218.

Johnson, M.A.; Prideaux, C.T.; Kongsuwan, K.; Sheppard, M. and Fahey, K.J. (1991): Gallid herpesvirus 1 (infectious Laryngotracheitis virus): cloning and physical maps of the SA2 strain, Arch. Virol., 119: 181-198.

Jordan, F.T.W. (1958): Some observations of infectious Laryngotracheitis. Vet Rec., 70: 605-610.

Keam, L.; York, J.J.; Sheppard, M. and Fahey, K.J. (1991): Detection of infectious Laryngotracheitis virus in chickens using a nonradioactive DNA probe. Avian Dis., 35: 257-262.

Key, D.W.; Gough, B.C.; Derbyshire, J.B. and Nagy, E. (1994): Development and evaluation of a non-isotypically labeled DNA probe for the diagnosis of infectious Laryngotracheitis. Avian Dis., 38: 467-474.

Kirkpatrick, N.C.; Mahmoudian, A.; Colson, C.A; Devlin, J.M. and Noormohammad, A.H. (2006): Relationship between mortality, clinical signs and tracheal pathology in infectious Laryngotracheitis Avian Pathol., 35: 449-453. 
Leib, D.A.; Bradbury, J.M.; Hart, C.A. and McCarthy, K. (1987): Genome isomerism in two alphaherpesviruses: herpesvirus saimiri-1 (herpesvirus tamarinus) and avian infectious Laryngotracheitis virus, Arch. Virol., 93: 287-294.

Mc Nulty, M.S.; Allan, G.M. and McCracken, R.M. (1985): Infectious Laryngotracheitis in Ireland. Irish Vet. J., 39: 124-125.

Office International des Epizooties (OIE) (2008): Avian Infectious Laryngotracheitis. Terrestrial Manual., page 456-463.

Ojkic, D.; Swinton1, J.; Vallieres, M.; Martin, E.; Shapiro, J.; Sanei, B. and Binnington1, B. (2006): Characterization of field isolates of infectious Laryngotracheitis virus from Ontario. Avian Pathol., 35: 286-292.

Oldoni, I.; Rodriguez-Avila, A.; Riblet, S. and Garcia, M. (2008): Characterization of Infectious Laryngotracheitis Virus (ILTV) Isolates from Commercial Poultry by Polymerase Chain Reaction and Restriction Fragment Length Polymorphism (PCR-RFLP). Avian Dis., 52: 59-63.

Roizman, B. and Pellet, P.E. (2001): The family Herpesviridae: a brief introduction. In Fields Virology, 4th edn, pp. 2381-2397. Edited by D. M. Knipe \& P. M. Howley. Philadelphia, PA: Lippincott Williams \& Wilkins.

Sellers, H.S.; Garcia, M.; Glisson, J.R.; Brown, T.P.; Sander, J.S. and Guy, J.S. (2004): Mild infectious Laryngotracheitis in broilers in the southeast. Avian Dis., 48: 430-436.

Timurkaan, N.; Yilmaz, F.; Bulut, H.; Ozer, H. and Bolat, Y. (2003): Pathological and immunohistochemical findings with a low virulent strain of infectious Laryngotracheitis virus. J.Vet. Sci., 4: $175-180$.

Tripathy, D.N. (1998): Infectious Laryngotracheitis. In: Swayne, D.E., Glisson, J.R., Jackwood, M.W., Pearson, J.E., Reed, W.M. (Eds.), A Laboratory Manual for the Isolation and Identification of Avian Pathogens. American Association of Avian Athologists, Kennett Square, PA, pp. 111-115.

Williams, R.A.; Bennett, M.; Bradbury, J.M.; Gaskell, R.M.; Jones, R.C. and Jordan, F.T.W. (1992): Demonstration of sites of latency of infectious Laryngotracheitis virus using the polymerase chain reaction. Journal of General Virology, 73: 2415-2420. 
Williams, R.A.; Savage, C.E. and Jones, R.C. (1994): A comparison of direct electron microscopy, virus isolation and a DNA amplification method for the detection of avian infectious Laryngotracheitis virus in field material. Avian Pathol., 23: 709-720.

Wojnarowicz, C. (2008): Infectious Laryngotracheitis in a backyard chicken flock. Animal Health Perspective, 4: page 3.

Van Kammen, A. and Spadbrow, P.B. (1976): Rapid diagnosis of some avian virus diseases. Avian Dis., 20: 748-751.

York, J.J. and Fahey, K.J. (1988): Diagnosis of infectious Laryngotracheitis using a monoclonal antibody ELISA. Avian Pathol., 17: 173-182. 